Table 5 Impact of inflation on working capital requirements

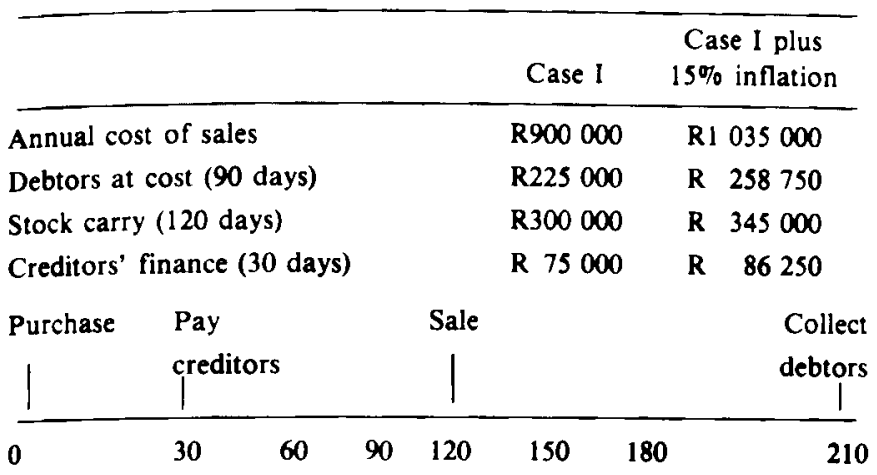

The working capital requirement changes as follows:

\begin{tabular}{lll}
\hline & Case I & $\begin{array}{c}\text { Case I plus } \\
15 \% \text { inflation }\end{array}$ \\
\hline Stock carry & $\mathbf{R 3 0 0 0 0 0}$ & R345 000 \\
Plus debtors & R225000 & R258750 \\
\cline { 2 - 3 } & R525000 & R603750 \\
Less creditors & R 75000 & R 86250 \\
\cline { 2 - 3 } & R450 000 & R517500
\end{tabular}

Annual finance charges at prime

bank overdraft rate of $20 \%$

R $90000 \quad$ R 103500

Increased interest charges as a result

of inflation

R 13500

Hence, 23,5 days reduction in cash flow cycle required to recoup R 13500 additional finance charges.

Om mee af te sluit: $\mathrm{U}$ moet sorg dat elke sent wat u beskikbare finansiering kan verdien 'n bydrae tot $u$ wins lewer, want finansiering is skaars en duur. Finansiering weier nie om oortyd te werk nie, dit neem ook nie verlof nie, dit word nie deur vakbonde beheer nie en slaap nie in die nag nie. Daarom moet u dit 24 uur per dag hard laat werk.

\section{HSRC Investigation into Intergroup Relations: The programme and its financing}

\author{
H.C. Marais and Lynette Dreyer \\ Human Sciences Research Council (HSRC), Private Bag X270, \\ Pretoria 0001, Republic of South Africa
}

\section{Introduction}

Economists in particular and social scientists in general are invited to participate in the HSRC Investigation into Intergroup Relations. A budget independent of the usual financing of research at universities is available for research into the most pressing aspects of the relationships between the major groups in South Africa.

This article provides information on the background to and management of the HSRC Investigation into Intergroup Relations. At the same time it is also an invitation to the research community to participate in the programme by applying for financial assistance.

\section{Background}

Research councils in most industrialized countries initiate and support problem-oriented research. In this way research can contribute towards a better understanding of the nature and process of pressing social problems. The Human Sciences Research Council since 1980 also administers a budget specifically provided for problemoriented research.

By their very nature social problems are multidimensional. The accent is therefore placed on the co-operation of as many researchers as possible from different research organizations, as it is obvious that a single organization in South Africa cannot approach a comprehensive problem multidisciplinarily, on its own. The co-operative approach also implies that such a problem can be approached from different ideological, theoretical and methodological perspectives simultaneously.

The first research programmes that were undertaken within this framework were the HSRC Investigation into Sport under the leadership of Prof. G.J.L. Scholtz of the Potchefstroom University for CHE, and the HSRC Investigation into Education under the leadership of Prof. J.P. de Lange of the Rand Afrikaans University.

From a survey that was conducted during 1980 , the field of intergroup relations emerged as the single most important area for research in South Africa (see HSRC Research Bulletin, 1981, 11(2), 1-3). Consequently the Research Priorities Committee representing the major research sectors in South Africa, recommended to the HSRC that a broad investigation into intergroup relations be undertaken. This recommendation was accepted and during 1981 planning started. The investigation was thus solely initiated by the HSRC.

\section{Research management and organization}

The HSRC Investigation into Intergroup Relations is managed and controlled by a main committee. The main committee consists of experts representing the sectors that have a direct interest in intergroup relations.

\section{Fields and work committees}

Because the research area, intergroup relations, is potentially so vast, following guidelines are necessary for the delineation of the investigation:

- The accent falls on the relations between the main population groups in South Africa like the Afrikaansand English-speaking Whites, urban and homeland Blacks, Coloureds, Indians and large immigrant groups.

- The basis on which the population is analysed (for example in terms of interest groups), will be partly determined by the theoretical stand of the researcher.

- The research is problem-oriented and thus focuses on the most topical aspects of intergroup relations.

The main committee divided the area into thirteen fields: Theory and methodology Historical aspect 
Juridical aspect

Social structures

Religion

Administrative aspect

Communication

Bibliography and databank

Geographic and demographic aspects

Social psychological aspect

Economics and labour

Constitution and politics

Race, ethnicity and culture

A work committee was appointed in each of these fields. An attempt was made to reflect in its composition the different points of departure in the study of intergroup relations. The functions of the work committees include the following:

- thematization and operationalization of research programmes and projects in the specific aspect of intergroup relations;

- stimulation of research interest in the research proposals;

- evaluation of research reports;

- integration of research reports into a comprehensive report.

\section{Infrastructural assistance to researchers}

Various infrastructural services are available to the researchers who participate by means of empirical or theoretical projects. This is over and above the financial assistance that researchers are invited to apply for. The main services, which in no way will influence the independence of participating researchers, are:

- a computerized bibliographic service;

- assistance in the designing of research projects and statistical analyses;

- access to country-wide representative-samples and a fieldwork infrastructure.

\section{Financial support}

The financing of research projects will be based on the regulations in the South African Plan for Research in the Human Sciences, par. 3.5. Funds are available for the following expenses:

- Salaries of researchers,

- Current expenses,

- Costs involved in research consultations and specialists,

- Overseas visits and congresses,

- Extraordinary capital equipment.

Applications for financial assistance must be made to the Secretariat of the HSRC Investigation into Intergroup Relations via the institution to which the researcher is attached. Application forms are available from the section for research administration of universities and from the Secretariat.

\section{Programme}

Because of the administration involved in an investigation of this size, the following programme will be followed:

- The return dates for the submission of research tenders for empirical as well as theoretical projects are 30 June, 31 October and 1 March of each year.

- Tenders that will rely on the infrastructural services of the HSRC must be received by March 1, 1983.

- The last date for the submission of reports on completed research contracts is August 1, 1984.

- During the last quarter of 1984 the work committees will integrate the projects done in their respective fields into a work committee report to be submitted before December 31, 1984.

- The comprehensive report of the main committee will be written during the first quarter of 1985 .

- The main committee report will be handed to the President of the HSRC at the end of March 1985.

\section{Research topics}

During meetings of the work committees a number of problem areas were identified for which research themes were formulated. The work committees were satisfied that these themes are indicative of the topics that warrant research attention to achieve a useful and comprehensive description and explanation of the nature and dynamics of intergroup relations in South Africa.

Every report that flows from the research and is adjudged to be of a suitable standard will be published as a separate report or as part of an integrated research report. The main committee will take the final decision in this regard.

The whole research community is invited to send research proposals with accompanying budgets to the Secretariat of the HSRC Investigation into Intergroup Relations for consideration. The themes within which research projects are awaited are listed below. Proposals on topics related to those specified will also be considered. Researchers who have recently completed projects that fit into the framework can therefore submit their reports and apply for funds to adapt these to the needs of the programme.

In conclusion the attention must be drawn to the idea behind this problem-oriented research programme, that is that the research to be undertaken must be aimed at contributing towards a better understanding of the nature and processes of intergroup relations in South Africa.

The work committee: economics and labour divided their field for research into economic resources, labour and economic change, with the following themes and priorities:

\section{Delineation of the field with the present situation as point} of departure

1. Access to and control of economic resources.

Access to land: distribution and level of development.

Distribution of wealth.

Capital: public and private.

Distribution of and access to education and training facilities.

Information on economic systems.

Access to the labour market (geographical and occupational mobility).

The distribution of economic power.

2. Conflict in the labour sphere.

The labour-capital dichotomy.

The relationship employer - employee.

Developing conciliation mechanisms.

Conflict within the labour movement and within management. 
Conflict between organized labour and the state. Differential perceptions of conflict (e.g. by management. labour, government).

3. Processes of economic change.

The rural-urban gap.

Urbanization.

First and third world economics.

\section{Defining priorities and trade-offs}

1. Perspectives of economic justice as a contributor to conflict.

2. The role of economic expectations.
3. Relative economic deprivation.

4. The potential effect of economic growth.

5. Employee participation and the control of means of production.

Other work committees suggested themes which might also be of interest to researchers in this field. They are available on request from the Secretariat, Investigation into Intergroup Relations, Human Sciences Research Council, Private Bag X270, PRETORIA 0001. Tel. 21-8624 × 81 or 88.

Further details on any aspects of the programme, and application forms can be obtained from the Director of the investigation at the same address. 